\title{
PENINGKATAN PRAKTEK BERWUDHU MELALUI METODE DEMONTRASI SISWA KELAS II SDN 44 SUNGAI LAREH KOTO TANGAH PADANG
}

\author{
Oleh : Iswandi ${ }^{1}$
}

\begin{abstract}
Purpose of humans is created to worship Allah SWT. The main and decisive worship for humans is worship of prayer. Valid or not prayer is determined by the validity of the ablution. Therefore ablution must be considered and carried out correctly and perfectly. Thus this study aims to determine the increasing practice of ablution through Demonstration Method in class II SDN 44 Sungai Lareh, Koto Tangah District, Padang. The students' results on the increase in ablution practices through the Demonstration Method in class II SDN 44 Sungai Lareh, Kota Tangah District, Padang. Supporting factors and inhibiting actors in capacity building through Demonstration Method for class II students at SDN 44 Sungai Lareh, Koto Tangah District, Padang. Teacher's Efforts to Overcome Obstacles in Increasing Ablution Practice through Demonstration Method for Class II students at SDN 44 Sungai Lareh, Koto Tangah District, Padang.

This research is the type of research used by researchers is classroom action research (CAR). It is research conducted by the teacher in his own class through self reflection, with the aim of improving his performance as a teacher so that student learning outcomes increase ". This research was conducted in Class II at SDN 44 Sungai Lareh, Koto Tangah District, Padang. In this study, researchers used several actors to collect data, namely: Student activity observation sheets, Learning outcomes tests, Observation of learning activities, Free interview techniques.
\end{abstract}

Keywords: Practice of ablution ', demonstration

\begin{abstract}
Abstrak
Tujuan manusia diciptakan adalah untuk beribadah kepada Allah SWT. Ibadah yang sangat utama dan menentukan bagi manusia adalah ibadah shalat. Sah atau tidaknya ibadah shalat ditentukan oleh sah atau tidaknya wudhu yang dilakukan. Oleh karena itu wudhu harus menjadi perhatian dan dilakukan dengan benar dan sempurna. Dengan demikian penelitian ini bertujuan untuk mengetahui Peningkatan praktek berwudhu melalui Metode Demontrasi di kelas II SDN 44 Sungai Lareh Kecamatan Koto Tangah Padang. Hasil siswa terhadap peningkatan praktek berwudhu melalui Metode Demontrasi di kelas II SDN 44 Sungai Lareh Kecamatan Kota Tangah Padang. Faktor pendukung dan 72actor penghambat dalam peningkatan kemampuan melalui Metode Demontrasi bagi siswa kelas II di SDN 44 Sungai Lareh Kecamatan Koto Tangah Padang. Upaya Guru Mengatasi Faktor Penghambat dalam Peningkatan Praktek Berwudhu melalui Metode Demontrasi bagi siswa kelas II di SDN 44 Sungai Lareh Kecamatan Koto Tangah Padang.

Penelitian ini adalah Jenis penelitian yang digunakan peneliti adalah penelitian tindakan kelas (PTK). Adalah penelitian yang dilakukan oleh guru didalam kelasnya sendiri melalui refleksi diri, dengan tujuan untuk memperbaiki kinerjanya sebagai seorang guru sehingga hasil belajar siswa meningkat". Penelitian ini dilakukan pada Kelas II di SDN 44 Sungai Lareh Kecamatan Koto Tangah Padang. Dalam penelitian ini, peneliti menggunakan beberapa 72actor72ent untuk mengumpulkan data, yaitu: Lembar observasi aktifitas siswa, Tes hasil belajar, Observasi kegiatan pembelajaran, Teknik wawancara secara bebas.
\end{abstract}

Kata kunci : Peningkatan, Praktek berwudhu, Demonstrasi

\footnotetext{
${ }^{1}$ Dosen Tetap STAI YAPTIP Pasaman Barat
} 


\section{Kata Kunci : Praktek Wudhu', Demonstrasi}

\section{A. Pendahuluan}

Tujuan manusia diciptakan oleh Allah swt. hanya untuk melakukan ibadah kepadaNya. Dengan demikian, ibadah merupakan kewajiban bagi manusia di waktu berada di atas dunia. Berbagai macam ibadah yang diperintahkan Allah swt. kepada manusia wajib melaksanakannya. Hal ini sesuai dengan firman Allah swt dalam surat adz-Dzariyat 56:

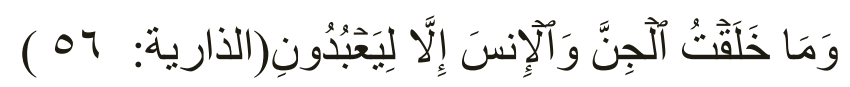

"Dan aku tidak menciptakan jin manusia melainkan supaya mereka mengabdi kepadaKu” (QS. Az-Zariyat : 56). (Departemen Agama RI, 2002 : 524)

Kewajiban melaksanakan ibadah perlu dilakukan dalam keadaan suci dari hadas dan najis (Norhadi, 2009 : 2). Menurut Harun Nasution (1992, 915) suci dari hadas dan najis merupakan amalan penting dalam hukum Islam. Banyak ibadah dalam Islam, misalnya ibadah shalat yang mensyaratkan suci dari hadats dan najis, atau dengan kata lain, bahwa yang menjadi syarat sahnya shalat adalah suci dari hadas dan suci badan, pakaian dan tempat dari najis. Dengan demikian jiwa raga yang suci merupakan faktor penting dalam melaksanakan ibadah serta sebagai syarat untuk diterimanya ibadah seseorang.

Salah satu ibadah yang mewajibkan umat Islam agar suci adalah ibadah shalat. Shalat merupakan kewajiban umat Islam yang paling utama. Karena shalat merupakan

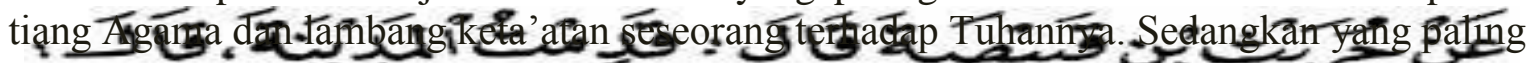

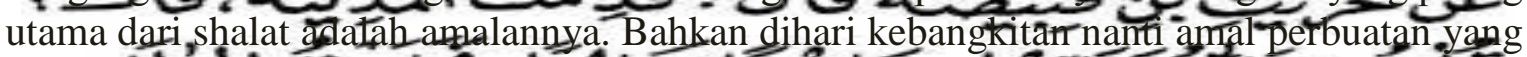

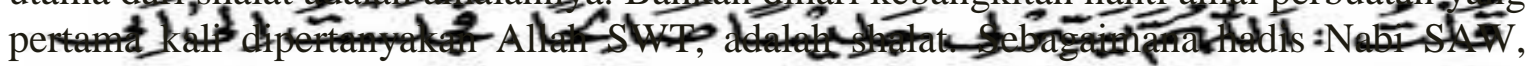

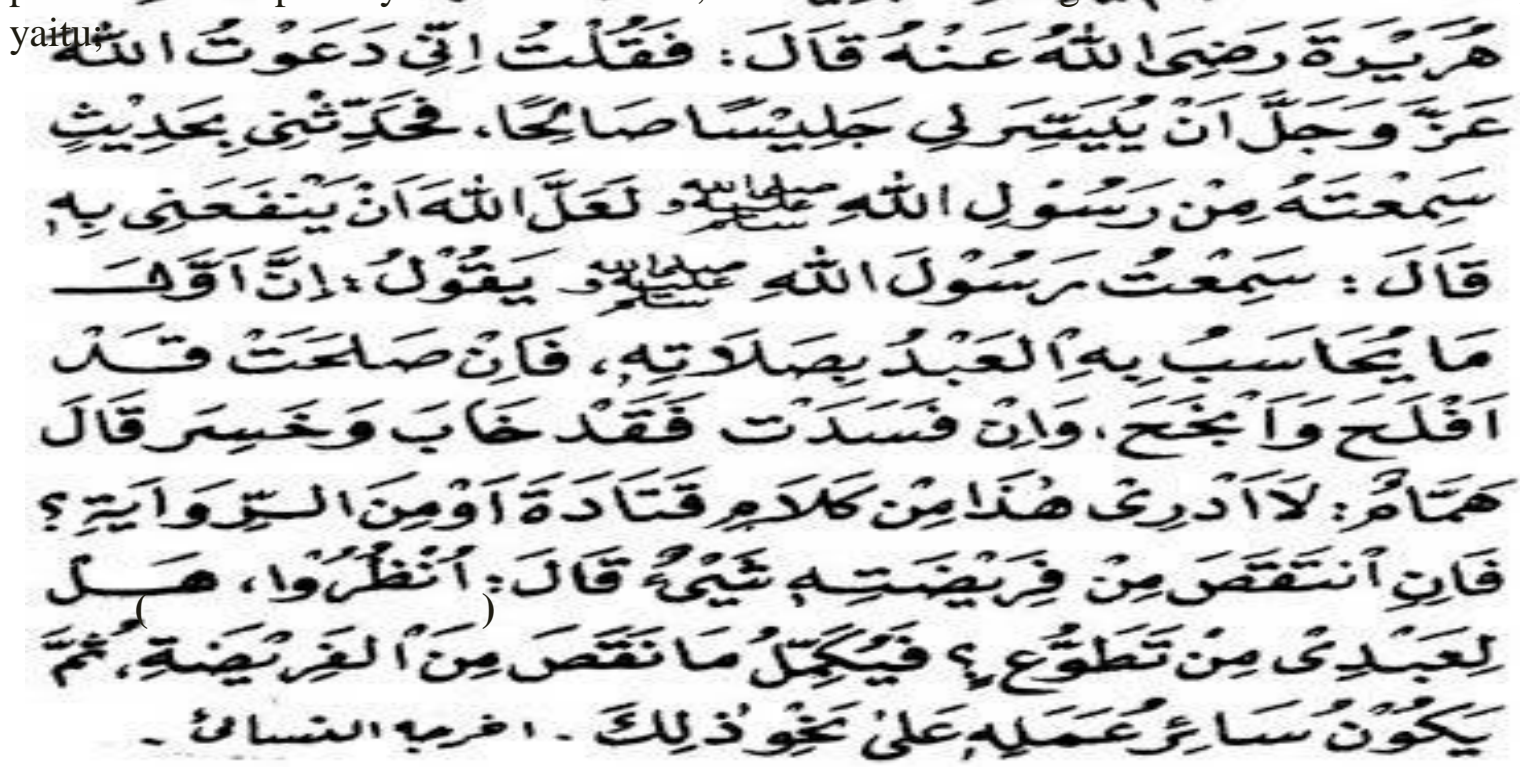

Artinya : Dari Huraits bin Qabishah, ia berkata : Saya sampai di Madinah. Ia berkata : "Wahai Allah mudahkanlah bagiku (mendapat) teman duduk yang baik. Lalu saya duduk kepada Abu Hurairah radhiyallahu 'anhu Ia berkata : Saya berkata : "Saya berdo'a kepada Tuhan (Allah) Yang Maha Mulia dan Maha Besar -untuk memudahkan bagiku teman duduk yang baik, maka sampaikanlah kepadaKu hadits yang kamu dengar dari Rasulullah Shalallahu 'alaihi wa sallam Semoga Allah memberi manfaat kepadaku dengan 
itu". Ia berkata : Saya mendengar Rasulullah saw. bersabda : "Sesungguhnya sesuatu yang paling dulu dihisab pada hamba adalah shalatnya. Jika shalat itu baik maka ia telah menang dan sukses. Jika shalatnya rusak maka ia telah merugi". Hammam berkata: Saya tidak tahu, ini dari perkataan Qatadah atau riwayat. Jika dari fardhunya ada kekurangankekurangan, Allah berfirman : "Lihatlah, apakah hambaKu mempunyai shalat sunnat, maka fardhu yang kurang itu dapat disempurnakan. Kemudian demikian itu caranya dalam menghisab seluruh amalnya". (Hadits ditakhrij oleh An Nasa'i).

Selanjutnya ibadah shalat dalam agama Islam mengandung nilai-nilai pengetahuan sikap atau perilaku bahkan keterampilan. Untuk itu pembinaan shalat harus diterapkan dari kecil sehingga dapat diamalkan sampai kapanpun. Dalam hal ini yang bertanggung jawab pertama dan utama dalam pembinaan shalat anak adalah orangtuanya (keluarga), jika orangtuanya tidak mampu untuk memberikan pelajaran terhadap anaknya karena faktor kesibukan atau kurangnya pengetahuan, maka hendaklah diserahkan kepada yang lebih mampu supaya anak-anak mereka terarah dalam menjalankan kehidupannya. (M. Arifin, 1994: 4).

Umat Islam yang akan melaksanakan shalat harus suci dari najis dan hadas. Supaya umat Islam suci dari hadas kecil, maka mereka harus melakukan wudhu'. Sebagaimana firman Allah SWT dalam Surat al Maidah 6 ; "Hai orang-orang yang beriman, apabila kamu hendak mengerjakan shalat, Maka basuhlah mukamu dan tanganmu sampai dengan siku, dan sapulah kepalamu dan (basuh) kakimu sampai dengan kedua mata kaki, dan jika kamu junub Maka mandilah, dan jika kamu sakit[403] atau dalam perjalanan atau kembali dari tempat buang air (kakus) atau menyentuh[404] perempuan, lalu kamu tidak memperoleh air, Maka bertayammumlah dengan tanah yang baik (bersih); sapulah mukamu dan tanganmu dengan tanah itu. Allah tidak hendak menyulitkan kamu, tetapi dia hendak membersihkan kamu dan menyempurnakan nikmat-Nya bagimu, supaya kamu bersyukur. (Departemen Agama RI, 2002 : 109).

Wudhu' merupakan kunci sah dan tidak nya shalat. Apabila wudhu' seseorang tidak sah, maka shalatnya tidak sah. Sedangkan apabila wudhu' sah, maka ada kemungkinan shalatnya bisa sah, kalau seseorang tidak melakukan larangan-larangan lainya. (Norhadi, 2009 : 12).

Wudhu' merupakan kunci dalam melaksanakan shalat, maka orang yang melaksanakan shalat disyaratkan suci dari hadas, baik hadas kecil maupun hadas besar. Wudhu' mempengaruhi sah tidaknya shalat. Dengan demikian wudhu' merupakan sesuatu yang sangat penting dalam ibadah shalat seseorang. Wudhu' perlu dilakukan dengan sempurna sesuai dengan aturannya.

Tidak hanya shalat, tetapi semua amalan ibadah yang membutuhkan suatu keadaan suci dari hadas kecil, semuanya kuncinya adalah wudhu'. (Norhadi, 2009 : 13). Dengan demikian wudhu' merupakan suatu langkah awal yang benar-benar harus sempurna sebelum melangkah pada amalan ibadah yang lainya. Setiap orang beriman diperintahkan untuk melaksanakan shalat, dan sebelum melaksanakan shalat diperintahkan untuk berwudhu'. Sebagaimana firman Allah SWT dalam al Maidah ayat 6;

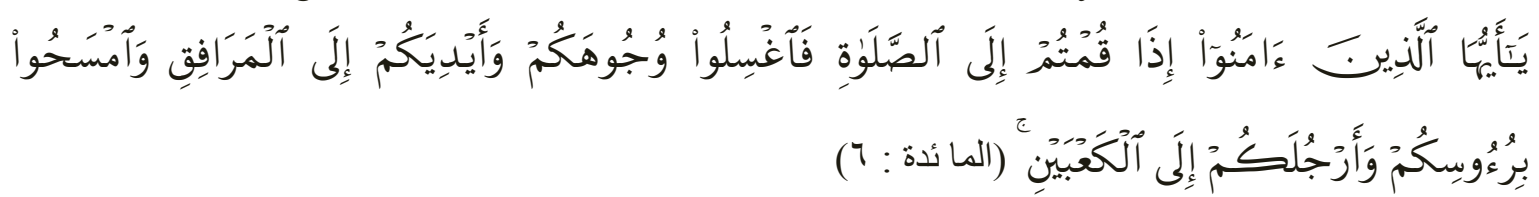

"Hai orang-orang yang beriman, apabila kamu hendak mengerjakan shalat, Maka basuhlah mukamu dan tanganmu sampai dengan siku, dan sapulah kepalamu dan (basuh) kakimu sampai dengan kedua mata kaki. . (Departemen Agama RI, 2002 : 109). 
Pelaksanaan berwudhu' harus seesuai dengan aturan yang disebutkan dalam firman Allh SWT. Ada bagian-bagian tubuh yang harus dibasuh dan diusap, yaitu membasuh muka, kedua tangan sampai siku, dan mengusap sebagian kepala, dan membasuh kaki sampai mata kaki. Berwudhu' pada prinsipnya menggunakan air, walaupun ketika kesulitan air boleh diganti dengan debu untuk bertayamum.

Berdasarkan ayat diatas dapat dipahami bahwa wudhu' merupakan sesuatu syarat sahnya dalam pelaksanaan ibadah shalat. Tanpa adanya wudhu', maka ibadah seperti shalat, tidak sah pelaksanaannya. Oleh karena itu praktek pelaksanaan wudhu' harus dilakukan dengan benar dan sempurna.

Pembelajaran tentang wudhu' pada jenjang pendidikan Sekolah Dasar penting dilakukan melalui metode Demontrasi. Metode Demontrasi dalam pembelajaran PAI juga sejalan dengan salah satu pedoman operasional penyusunan kurikulum yaitu untuk peningkatan iman dan taqwa serta akhlak mulia. Menurut E. Mulyasa (2005 : 168) Keimanan dan ketaqwaan serta akhlak mulia yang menjadi dasar pembentukan kepribadiaan peserta didik secara utuh. Dengan demikian, kurikulum disusun sesuai dengan semua mata pelajaran, yang dapat menunjang peningkatan iman dan taqwa serta akhlak mulia.

Proses pembelajaran merupakan rangkaian kegiatan. Mulai dari masuk kelas, ketika proses pembelajaran berlangsung, sampai keluar kelas merupakan bentuk-bentuk kegiatan demontrasi dalam pembelajaran. Guru yang propesional dalam membentuk berbagai kebiasaan yang baik dalam kelas akan membentuk peserta didik yang berkualitas. Hal ini dikarenakan bahwa belajar kebiasaan adalah proses pembentukan kebiasaankebiasaan baru atau perbaikan kebiasaan-kebiasaan yang telah ada. Belajar kebiasaan, selain menggunakan perintah, suri tauladan dan pengalaman khusus juga menggunakan hukuman dan ganjaran. Tujuannya agar siswa memperoleh sikap-sikap dan kebiasaankebiasaan perbuatan baru yang lebih tepat dan positif dalam arti selaras dengan kebutuhan ruang dan waktu (kontekstual). Selain itu arti tepat dan positif diatas ialah selaras dengan norma dan tata nilai moral yang berlaku baik yang bersifat religius maupun tradisional dan kultural. (Muhibbin Syah, 2000 : 123).

Beberapa bentuk demontrasi dalam kelas adalah membaca, mendengar, melihat dan melakukan. Guru bisa memanfaatkan beberapa demontrasi ini dengan maksimal, akan mempengaruhi kepada prestasi belajar siswa.

Berdasarkan kutipan di atas dapat dipahami bahwa metode Demontrasi dilaksanakan disekolah maupun diluar sekolah, seperti berbicara sopan. Di samping dalam materi wudhu', metode Demontrasi sangat tepat dilakukan, apalagi bagi siswa kelas II yang perlu banyak praktek dan demontrasi agar keterampilan wudhu' dapat dikuasai oleh peserta didik.

B. Metode Peneltiain

1. Jenis dan Metode Penelitian

Jenis penelitian yang digunakan peneliti adalah Penelitian Tindakan Kelas(PTK). Menurut I.G.A.K Wardani (2004:1.4), 'PTK adalah penelitian yang dilakukan oleh guru didalam kelasnya sendiri melalui refleksi diri, dengan tujuan untuk memperbaiki kinerjanya sebagai seorang guru sehingga hasil belajar siswa meningkat". Tujuan PTK yaitu : Meningkatkan kualitas mengajar guru dan Meningkatkan hasil belajar siswa.

kutipan

2. Lokasi dan Waktu Penelitian

Penelitian ini dilakukan di SDN 44 Sungai Lareh Koto Tangah Padang, dengan pertimbangan: sekolah bersedia menerima inovasi pendidikan terutama dalam proses pembelajaran dan peneliti sudah mengenal SD tersebut. 
Penelitian ini dilaksanakan pada semester 1, terhitung dari waktu perencanaan sampai penulisan laporan hasil penelitian. Sedangkan pelaksanaan tindakan dimulai tanggal 1-30 Februari 2017.

3. Populasi dan Sampel

Penelitian didalam pelaksanaannya, terdapat komponen permasalahan yang mutlak dibutuhkan. Adapun komponen tersebut adalah populasi dan sampel penelitian.

Dalam penelitian ini, populasi penelitiannya adalah seluruh siswa Kelas II SDN 44 Sungai Lareh Koto Tangah Padang yang berjumlah 20 orang. Sebagaimana dikatakan Suharsimi Arikanto bahwa apabila subyek kurang dari 100 lebih baik diambil semua sehingga penelitiannya merupakan peneltian populasi. (Suharsimi Arikanto, 2002, 120). Suharsimi Arikanto mendefenisikan lebih lanjut bahwa yang dimaksud dengan populasi adalah keseluruhan subyek penelitian.Sedangkan munurut Sugiyono, populasi adalah wilayah generalisasi yang terdiri atas subyek/obyek yang mempunyai kuantitas dan karakteristik tertentu yang ditetapkan oleh peneliti untuk dipelajari dan kemudian ditarik kesimpulannya. (Sugiono,2008, 117). Karena jumlah siswa hanya berjumlah 20 orang yang mana kurang dari 100, maka peneliti menggunakan semua siswa untuk dijadikan subyek penelitian.

\section{Instrumen Penelitian}

Dalam penelitian ini, peneliti menggunakan beberapa instrumen untuk mengumpulkan data, yaitu:

1. Lembar observasi aktifitas siswa

Digunakan untuk mendapatkan informasi apakah dengan menggunakan metode demontrasi dapat ditingkatkan aktivitas belajar siswa.

2. Tes hasil belajar

Tes hasil belajar digunakan untuk mendapatkan data hasil belajar pada setiap siklus serta dilakukan tes pelaksanaan shalat.

3. Observasi kegiatan pembelajaran

Dilakukan untuk mengamati berlangsungnya proses pembelajaran PAI. Dengan berpedoman pada lembar observasi ini, peneliti mengamati apa yang terjadi dalam proses pembelajaran berlangsung.

4. Teknik wawancara secara bebas

Dilakukan mengungkap data yang perlu diungkapkan dengan kata-kata secara lisan tentang sikap, pendapat, wawasan siswa mengenai baik buruknya proses pembelajaran yang berlangsung terkait dengan aktivitas belajar PAI.

\section{Teknik Pengumpulan Data}

Penelitian ini merupakan penelitian tindakan (action research), menurut Isaac (1971) teori dengan lengkap Penelitian Tindakan Kelasini didesain untuk memecahkan masalah-masalah yang diaplikasikan secara langsung di dalam ajang kelas atau dunia kerja. Menurut Oja dan Sumarjan (dalam Titik Sugiarti, 1997: 8) mengelompokkan penelitian tindakan di bagi menjadi empat macam yaitu, (1) guru sebagai peneliti, (2) penelitian tindakan kolaboratif, (3) simultan terintegratif, dan (4) administrasi sosial eksperimental. Dalam Penelitian Tindakan Kelasini menggunakan bentuk kolaborasi, yang mana guru merupakan mitra kerja peneliti. Masing-masing memusatkan perhatiannya pada aspek-aspek Penelitian Tindakan Kelasyang sesuai dengan keahliannya, guru sebagai praktisi pembelajaran, peneliti sebagai perancang dan pengamat yang kritis. Sesuai dengan jenis penelitian yang dipilih, yaitu penelitian tindakan, maka penelitian ini menggunakan model penelitian tindakan dari Kemmis dan Taggart (dalam Sugiarti, 1997: 6), yaitu berbentuk spiral dari sklus yang satu ke siklus yang berikutnya. Setiap siklus meliputi planning (rencana), action dan reflection (refleksi). 
Langkah pada siklus berikutnya adalah perencanaan yang sudah direvisi, tindakan, pengamatan, dan refleksi. Sebelum masuk pada siklus 1 dilakukan tindakan pendahuluan yang berupa identifikasi permasalahan. Siklus spiral dari tahap-tahap Penelitian Tindakan Kelasdapat dilihat pada gambar berikut :

Hubungan kelima komponen tersebut merupakan suatu siklus dan digambarkan pada Tabel dibawah ini:

\section{Bagan 2.}

Siklus

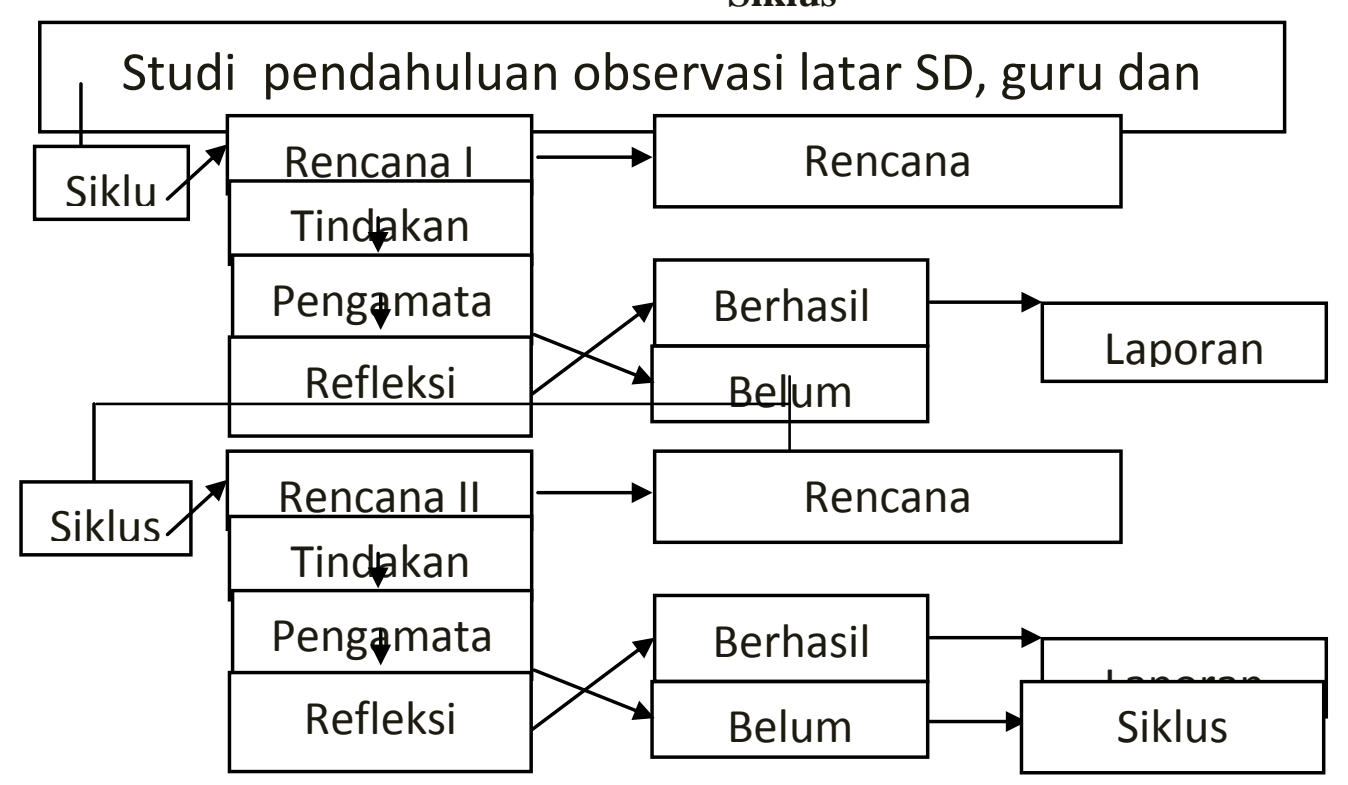

Posedur penelitin dilakukan empat tahap yaitu: langkah yang terdiri dari perencanaan tindakan (planning), pelaksanaan tindakan (acting), observasi (observing), refleksi (reflecting). Secara rinci dapat digambarkan sebagai berikut :

1. Pra siklus

a. Perencanaan Tindakan.

Kegiatan perencanaan tindakan meliputi hal berikut;

1) Guru menyampaikan kepada siswa bahwa nantinya beberapa kedepan untuk materi wudhu' akan diadakan penelitian supaya siswa bisa bekerja sama dengan baik.

2) Guru menentukan materi yaitu tentang kemampuan wudhu' siswa.

3) Guru menyiapkan administrasi pembelajaran pada materi wudhu' yaitu membuat RPP.

b. Pelaksanaan Tindakan

Kegiatan pelaksanaan tindakan meliputi hal berikut;

1) Guru membuka pelajaran dengan berdo'a bersama.

2) Guru mengabseni siswa.

3) Guru melakukan apersepsi sebelum memulai pelajaran, yaitu yang berisi pertanyaan-pertanyaan tentang pelajaran yang lalu dan juga berisi motivasi tentang tujuan dan manfaatnya ketika mempelajari materi berwudhu'.

4) Guru memulai masuk proses pembelajaran dengan menerangkan dan sunnah wudhu', syarat air yang bisa digunakan berwudhu' dan manfaat kita melakukan wudhu'.

5) Guru menjelaskan materi wudhu' hanya menggunakan metode konvensional saja (ceramah).

6) Sebelum menutup pembelajaran guru memberi kesempatan kepada siswa untuk bertanya jika ada yang masih belum jelas. 
7) Guru menyimpulkan pelajaran

c. Observasi

1) Guru memantau proses pembelajaran.

2) Guru mengamati aktifitas siswa.

3) Guru mengamati keselarasan perencanaan terhadap pelaksanaan.

4) Guru mengadakan evaluasi pembelajaran.

d. Refleksi

1) Guru mencatat segala hambatan selama melakukan pembelajaran.

2) Guru menganalisa faktor yang menjadi penghalang terjadinya proses pembelajaran.

3) Guru mencari solusi dari fakto-faktor penghambat untuk dijalankan pada siklus selanjutnya

2. Siklus 1

a. Perencanaan Tindakan

1) Menentukan materi yaitu pada standar kompetensi melaksanakan tata cara wudhu' pada kompetensi dasar mempraktekkan wudhu' di kelas II tahun ajaran 2016/2017.

2) Menentukan metode pembelajaran yaitu menggunakan alat peraga gambar.

3) Menyiapkan rencana pelaksanaan pembelajaran (RPP) dan peraga yang diperlukan.

4) Mengembangkan skenario pembelajaran, dari rencana pembelajaran hingga saat praktek.

5) Membuat lembar pantauan siswa tentang pelaksanaan wudhu' dirumah.

6) Membentuk kelompok yang heterogen. Peserta didik dibagi menjadi 5 (lima) kelompok dengan setiap kelompoknya beranggotakan 6 orang.

7) Menyiapkan format evaluasi yang berupa lembar penilaian tes prakti

b. Pelaksanaan Tindakan

1) Setelah menyiapkan apa yang dibutuhkan dalam pembelajaran, termasuk RPP dan peraga, guru mulai mempelajarinya dengan seksama supaya dalam pelaksanaannya bisa berjalan lancar.

2) Guru melaksanakan pembelajaran tentang wudhu' dimulai dengan,apersepsi, dikegiatan ini guru memberi motivasi kepada siswa tentang pentingnya, manfaat dan juga hukuman bagi yang meninggalkannya, supaya siswa mengetahui secara mendasar tentang wudhu'. Jadi ketika melaksanakan kewajiban wudhu' tidak dianggap sekedar sebagai rutinitas, tetapi mengetahui secara substansi arti wudhu' tersebut

3) Kemudian dilanjutkan pada kegiatan ini. Pada kegiatan ini guru memulai pembelajaran dari hal yang paling awal orang belajar wudhu', yaitu mengetahui tentang rukun dan sunnah wudhu', dilanjutkan bacaan-bacaannya. Pada tahap ini guru perlu membahas lebih mendalam lagi, tidak sekedar hafal bacaan- bacaan wudhu',tetapi sekalian mengetahui artinya. Karena pada tataran siswa kelas II usia siswa sudah memasuki usia untuk diperintah melaksanakan ibadah secara mandiri.

4) Setelah dirasa siswadalam bacaan sudah bisa kemudian untuk gerakan wudhu'nya, guru memperlihatkan gambar-gambar orang ketika berwudhu' mulai dari awal dicontohkan secara terpotong-potong pada tiap-tiap bagian gerakan wudhu' secara sempurna.

5) Setelah guru memperlihatkan secara keseluruhan dan siswa mengamati.

6) Kemudian guru menghimbau kepada para siswa untuk melaksanakan shalat.

c. Observasi 
Observasi dengan mengamati terjadinya aktifitas belajar siswa, dengan ditandai kefasihan melafadzkan bacaan dalam wudhu', kesempurnaan gerakannya, dilihat dari sikap ketika melakukan wudhu'.

d. Refleksi

1) Menilai hasil tindakan dengan menilai siswa.

2) Melakukan evaluasi tindakan yang telah dilakukan.

3) Memperbaiki pelaksanaan tindakan sesuai hasil evaluasi untuk digunakan pada siklus berikutnya.

3. Siklus 2

a. Perencanaan

1) Mengidentifikasi masalah berdasarkan refleksi siklus I dan alternatif pemecahan masalahnya.

2) Guru menampung semua permasalan yang muncul setelah siswa melakukan siklus I.

3) Menyusun Rencana Pelaksanaan Pembelajaran (RPP) pada pokok bahasan yang sama dengan materi yyang berbeda dari siklus I melalui pengelolaan kelas yang lebih efektif.

4) Guru menyiapkan kembali lembar pengamatan yang meliputi lembar pengamatan aktivitas siswa dalam praktek maupun dalam kegiatan pembelajaran.

b. Pelaksanaan Tindakan

Kegiatan yang dilaksanakan tahap ini yaitu Pengembangan rencana tindakan II dengan melaksanakan tindakan dalam upaya lebih meningkatkan semangat belajar peserta didik dalam pembelajaran wudhu' menggunakan alat peraga gambar yang telah direncanakan. Secara rinci dapat diuraikan sebagai berikut:

1) Guru melaksanakan langkah-langkah kegiatan yang tercantum dalam RPP mulai dari kegiatan awal pembelajaran. Guru lebih menekankan agar siswa lebih fokus dalam belajar dan semangat supaya hasilnya bisa maksimal.

2) Guru menjelaskan materi yang telah direncanakan pada kegiatan inti dimulai dari yang dirasa kurang dari evaluasi pada siklus I, jadi tidak mengulang dari awal, tinggal mengulang yang kurang-kurang saja.

3) Guru selau memantau pada setiap kelompok untuk ikut aktif dalam proses pembelajaran.

4) Setiap kelompok dibentuk Ketua Kelompok untuk selalu mengawasi kelompoknya dan melaporkan hasil kelompoknya. Dan Ketua Kelompok dipilih dari siswa yang dilihat sudah bisa.

5) Guru bersama para ketua kelompok membahas hasil para anggotanya dan mencari solusi kesulitan yang dihadapi para siswa.

c. Obsevasi

Guru mencatat semua proses yang terjadi dalam tindakan model pembelajaran, mendiskusikan tantang tindakan II yang telah dilakukan, dan juga kesulitan yang mungkin dihadapi para siswa setelah melakukan siklus II.

d. Refleksi

1) Tes evaluasi pembelajaran wudhu' menggunakan alat peraga gambar disekolah.

2) Menganalisis hasil pengamatan untuk memperoleh gambaran bagaimanakah dampak dari tindakan yang dilakukan, hal apa saja yang perlu diperbaiki sehingga diperoleh hasil refleksi kegiatan yang telah dilakukan. 
Indikator keberhasilan dalam proses pembelajaran diukur dengan menggunakan Kriteria Ketuntasan Minimum (KMM). KKM pada mata pelajaran PAI adalah 70\%, dan indikator keberhasilan proses pembelajaran khusus seputar aktivitas siswa adalah $75 \%$ sebagai berikut:

1. Meningkatnya pelaksanaan wudhu' siswa melalui penggunaan metode demontrasi di SDN 44 Sungai Lareh Koto Tangah Padang.

2. Meningkatnya respon siswa dalam penggunaan metode Demontrasi dalam peningkatan shalat siswa di SDN 44 Sungai Lareh Koto Tangah Padang.

\section{Teknik Pengolahan dan Analisa Data}

Data yang diperoleh dalam penelitian dianalisis dengan menggunakan model Analisis Kualitatif dan Kuantitatif. Analisis kualitatif menggunakan model analisis data kualitatif yang ditawarkan oleh Rochiati (2007: 135)yakni analisis data dimulai dengan menelaah sejak pengumpulan data sampai seluruh data terkumpul. Data tersebut direduksi berdasarkan masalah yang diteliti, diikuti penyajian data dan terakhir penyimpulan dan verifikasi. Tahap analisis tersebut diuraikan sebagai berikut:

1. Menelaah data yang terkumpul baik melalui observasi, dokumentasi, dan evaluasi dengan melakukan proses transkip hasil pengamatan, penyeleksian dan pemilihan data seperti mengelompokkan data pada siklus satu (1) dan siklus dua (2). Kegiatan menelaah data dilaksanakan sejak awal dikumpulkan.

2. Reduksi data meliputi pengkategorian dan pengklasifikasikan. Semua data yang telah terkumpul diseleksi dan dikelompok-kelompokkan sesuai dengan fokus data yang telah dipisah-pisahkan tersebut. Lalu diseleksi mana yang relavan dan mana yang tidak relavan. Data yang relavan dianalisis, dan data yang tidak relavan dibuang.

3. Menyajikan data dilakukan dengan cara mengorganisasikan informasi yang sudah direduksi. Data tersebut mula-mula disajikan terpisah, tetapi setelah tindakan terakhir, direduksi, keseluruhan data tindakan dirangkum dan disajikan secara terpadu sehingga diperoleh sajian tunggal berdasarkan fokus pembelajaran PAI dengan menggunakan metode demontrasi.

4. Menyimpulkan hasil penelitian, kegiatan ini merupakan penyimpulan akhir temuan penelitian pada kelas.

5. Tringulasi data, kegiatan ini berguna untuk mengecek kebenaran maupun penafsirannya. Kegiatan trigulasi data dilakukan dengan cara: 1) peninjauan kembali catatan lapangan, 2) teknik pengumpulan data ganda jika memungkinkan, 3) meminta subjek penelitian membaca penelitian untuk mengetahui kebenaran penafsiran dan kesimpulan peneliti dan 4) bertukar pikiran dengan ahli, teman sejawat, dan guru serta kepala sekoalah.

6. Analisis data dilakukan terhadap data yang direduksi, baik data perencanaan, pelaksanaan maupun data evaluasi. Analisis data dilakukan dengan cara terpisahpisah. Hal ini dimaksudkan agar data ditemukan berbagai informasi yang spesifik dan terfokus pada berbagai informasi yang mendukung pembelajaran dari yang menghambat pembelajaran. Dengan demikian, pengembangan dan perbaikan atas berbagai kekurangan dapat dilakukan tepat pada aspek yang bersangkutan.

7. Sedangkan model analisis data kuantitatif terhadap partisipasi siswa dengan menggunakan persentase yang didapat melalui lembar observasi siswa. Untuk melihat proses dan perkembangan partisipasi yang terjadi selama pembelajaran berlangsung.

$$
\mathrm{P} \%=\frac{\text { Jumlah Siswa yang Melakukan Indikator }}{\text { Jumlah Siswa Seluruhnya }} \times 100 \%
$$

Keterangan:P\%=Persentase siswa yang aktif dalam indicator 
Penilaian partisipasi siswa menurut Dimyati dan Mudjono (2006:125) menggunakan pedoman sebagai berikut;

$$
\begin{array}{ll}
1 \%-25 \% & =\text { Sedikit sekali } \\
26-50 \% & =\text { Sedikit } \\
51-75 \% & =\text { Banyak } \\
76 \%-100 \% & =\text { Banyak sekali }
\end{array}
$$

Rata-rata persentase partisipasi siswa dari satu siklus yang terdiri dari tiga pertemuan dibandingkan dengan rata-rata persentase pada siklus berikutnya. Jika ratarata persentase tersebut telah meningkat $25 \%$, maka baru dikatakan partisipasi siswa meningkat.

Sedangkan analisis data pengelolaan pembelajaran oleh guru adalah data hasil observasi kegiatan guru yang digunakan untuk melihat proses dan perkembangan guru dalam mengola pembelajaran yang terjadi selama pembelajaran berlangsung. Kemudian data tersebut dianalisis dengan teknik persentase. Untuk mendapatkan persentase guru dalam mengola pembelajaran, skor dari semua aspek dalam proses pembelajaran dihitung dengan rumus: persentase guru dalam mengola pembelajaran dengan total skor maksimal 15.

$$
\text { Penentuan skor }=\frac{\text { jumlah skor yang diperoleh }}{\text { Jumlah skor maksimal }} \times 100 \%
$$

Kegiatan guru mengola proses pembelajaran dikatakan baik jika guru melakukan aspek yang diamati pada proses pembelajaran diperoleh persentase $80 \%$. Setelah didapat persentase guru dalam mengelola pembelajaran pada setiap pertemuan, persentase tersebut dihitung rata-ratanya persiklus sehingga penilaian kegiatan guru dalam mengelola kelas dilihat dari rata-rata persentase persiklus jika mencapai $80 \%$, maka kegiatan guru mengelola pembelajaran dianggap baik. Untuk menentukan persentase hasil belajar siswa secara klasikal dapat digunakan rumus oleh Rita, dkk (2008:43).

$$
\mathrm{TB}=\frac{\mathrm{s}}{\mathrm{n}} \mathrm{x} 100 \%
$$

Keterangan :

$\mathrm{TB}=$ Tuntas belajar

$\mathrm{S}=$ julah siswa yang memperoleh nilai dari satu sama dengan 65

$\mathrm{N}=$ jumlah siswa

Nilai rata-rata hasil belajar siswa dapat dihitung dengan rumus oleh Sudjana (2002:67) yaitu:

Keterangan :

$$
X=\frac{\mathbb{E}}{n}
$$

$\mathrm{X}=$ nilai rata-rata

$\sum=$ jumlah nilai seluruh siswa

$\mathrm{N}=$ jumlah siswa

Hasil analisis dalam meningkatkan hasil belajar dalam pembelajaran PAI dikatakan berhasil apabila setelah diadakan tes pada akhir pembelajaran, siswa mendapatkan nilai rata-rata melebihi Kriteria Ketuntasan Minimal (KKM) yang telah ditetapkan di sekolah yaitu 70. Hal ini berarti penggunaan metode PAI di SDN 44 Sungai Lareh.

Data yang diperoleh dalam penelitian ini nantinya akan dianalisis dengan menggunakan data Kualitatif yang mengacu kepada teknik pengumpulan dan analisis data Kualitatif yang mengacu kepada teknik pengumpulan dan analisis data penelitian 
kualitatif yang dirancang oleh Sanafiah Faisal (dalam Burhan Bungin, 2003:70).

Tahapan analisis data tersebut dapat diuraikan sebagai berikut:

1. Menelaah data yang telah terkumpul baik melalui observasi dan pencacatan dengan menggunakan proses transkrip hasil pengamatan, penyeleksian, dan pemilihan data. Hal ini misalnya mengelompokkan data pada siklus I, dan siklus II. Kegiatan menelaah dan dilaksanakan sejak awal.

2. Reduksi data, meliputi pengkategorian dan pengaklasifikasian data. Semua data yang terkumpul diseleksi dan dikelompokkan sesuai dengan pusatnya.

3. Menyajikan data dilakukan dengan cara mengorganisir informasi yang telah direduksi. Data tersebut mula-mula disajikan terpisah, tetapi setelah tindakan terakhir akan dilakukan reduksi data. Keseluruhan data tindakan akan dirangkum dan disajikan secara terpadu sehingga diperoleh sajian tunggal berdasarkan fokus pembelajaran PAI melalui penggunaan metode demontrasi.

4. Kesimpulan, bisa berbentuk sketsa, synopsis, table, atau bentuk-bentuk lain. Hal itu sangat diperlukan untuk memudahkan upaya pemaparan dan penegasan kesimpulan.

Analisis data dilakukan terhadap data yang telah direduksi baik perencanaan, pelaksanaan, dan data evaluasi secara terpisah-pisah dengan tujuan menemukan informasi yang spesifik dan terfokus pada proses pembelajaran dan penghambat pembelajaran. Sehingga mendapatkan kesimpulan penelitian yang tepat sesuai dengan batasan masalah yang telah ditetapkan.

Hasil analisis dalam meningkatkan aktivitas siswa dalam pembelajaran PAI Kelas II SDN 44 Sungai Lareh Koto Tangah Padang melalui metode demontrasi dapat dikatakan berhasil apabila di waktu pembelajaran berlangsung siswa tidak main-main dalam mengikuti pembelajaran, siswa bisa mengidentifikasi ide-ide pokok dan ide-ide penunjang, siswa mengerjakan latihan dan pekerjaan rumah (PR) yang diberikan guru, dan setelah diadakan tes pada akhir pembelajaran PAI maka nilai rata-rata siswa diatas KKM yang telah ditetapkan disekolah tersebut (75).

Jika hal-hal diatas bisa tercapai/terjadi, berarti penggunaan metode demontrasi dapat dikatakan dapat meningkatkan aktivitas siswa kelas II dalam pembelajaran PAI di SDN 44 Sungai Lareh Koto Tangah Padang, terutama meningkatkan praktek berwudhu' bagi siswa-siswi di SDN 44 Sungai Lareh Koto Tangah Padang.

\section{Metode Demonstrasi}

1. Pengertian Metode Demonstrasi

Menurut Djamarah (1997:102-103) metode Demonstrasi adalah cara penyajian bahan pembelajaran dengan meragakan atau mempertunjukkan kepada siswa suatu proses, situasi, atau benda tertentu yang sedang dipelajari, baik sebenarnya ataupun tiruan, yang sering disertai dengan penjelasan lisan. Dengan metode Demonstrasi, proses penerimaan siswa terhadap pelajaran akan lebih berkesan secara mendalam, sehingga membentuk pengertian dengan baik dan sempurna. Juga siswa dapat mengamati dan memperhatikan apa yang diperlihatkan selama pelajaran berlangsung.

Metode demonstrasi baik digunakan untuk mendapatkan gambaran yang lebih jelas tentang hal-hal yang berhubungan dengan proses mengatur sesuatu, proses bekerjanya sesuatu, proses mengerjakan atau menggunakannya, komponen-komponen yang membentuk sesuatu, membandingkan suatu cara dengan cara yang lain, dan untuk mengetahui atau melihat kebenaran sesuatu.

2. Langkah-langkah Metode Demonstrasi

Adapun langkah-langkah metode Demonstrasi antara lain:

a. Menentukan tujuan demonstrasi yang akan dilakukan

b. Menentukan materi yang akan didemonstrasikan 
c. Menyiapkan fasilitas penunjang demostrasi seperti peralatan, tempat dan mungkin juga biaya yang dibutuhkan.

d. Penataan peralatan dan kelas pada posisi yang baik

e. Mempertimbangkan jumlah siswa dihubungkan dengan hal yang akan didemonstrasikan agar siswa dapat melihat dengan jelas.

f. Membuat garis besar atau pokok-pokok yang akan didemonstrasikan secara beruntun dan tertulis dipapan tulis atau pada kertas lembar, agar dapat dibaca siswa dan guru secara keseluruhan.

g. Untuk menghindarkan kegagalan dalam pelaksanaan, sebaiknya demonstrasi yang direncanakan dicoba terlebih dahulu.

3. Pelaksanaan Demonstrasi

Setelah segala sesuatu direncanakan dan dipersiapkan, langkah berikutnya adalah mulai melaksanakan demontrasi. Beberapa hal yang perlu diperhatikan antara lain :

a. Sebelum memulai, periksalah sekali lagi kesiapan peralatan yang akan didemontrasikan, tempat dan pokok-pokok yang akan didemonstrasikan.

b. Siapkanlah siswa, barang kali ada beberapa hal yang perlu dicatat.

c. Mulailah demonstrasi dengan menarik perhatikan siswa, ingat pokok-pokok materi yang akan didemonstrasikan agar dapat mencapai sasaran.

d. Ingatlah pokok-pokok materi yang akan disampaikan agar demontrasi mencapai sasaran.

e. Pada waktu berjalannya demonstrasi, sekali-kali perhatikan keadaan siswa apakah semua mengikuti dengan baik.

f. Untuk menghindari ketegangan ciptakan suasana yang harmonis.

g. Berikanlah kesempatan kepada siswa untuk secara aktif memikirkan lebih lanjut tentang apa yang dilihat dan didengar.

4. Tindak Lanjut dan Evaluasi

Sebagai tindak lanjut setelah dilaksanakan, suatu demontrasi sering diiringi dengan kegiatan-kegiatan belajar selanjutnya. Kegiatan ini dapat berupa pemberian tugas tertentu, misal tugas membuat laporan, tugas menjawab pertanyaan atau masalah dan mengadakan latihan atau percobaan lebih lanjut yang mungkin diselesaikan siswa.

5. Kekurangan Metode Demonstrasi

Menurut Djamarah (1997:104) kekurangan metode Demonstrasi yaitu;

a. Metode ini memerlukan keterampilan guru secara khusus, karena tanpa ditunjang hal itu, pelaksanaan demonstrasi akan tidak efektif.

b. Fasilitas seperti peralatan, tempat, dan biaya yang memadai tidak selalu tersedia dengan baik.

c. Demonstrasi memerlukan kesiapan dan perencanaan yang matang disamping memerlukan waktu yang cukup panjang, yang mungkin terpaksa mengambil waktu atau jam pelajaran lain.

6. Kelebihan Metode Demonstrasi

a. Dapat membuat pengajaran menjadi lebih jelas dan lebih konkret, sehingga menghindari verbalisme (pemahaman secara kata-kata atau kalimat).

b. Siswa lebih mudah memahami apa yang dipelajari.

c. Proses pengajaran lebih menarik.

d. Siswa dirangsang untuk aktif mengamati, menyesuaikan antara teori dengan kenyataan, dan mencoba melakukannya sendiri. 


\section{Hasil Penelitian Yang Relevan}

Adapun penelitian yang relavan adalah penelitian yang dilakukan oleh Fadlu Rozak (2012) yang meneliti tentang Peningkatan Kemampuan Wudhu' Siwa Melalui Penggunaan Alat Peraga Gambar pada Materi Wudhu' Kelas II SD Negeri 35 Pegambiran Padang. Hasil penelitiannya mengemukakan bahwa pelajaran PAI pada materi wudhu' dengan media gambar dapat meningkatkan prestasi belajar siswa kelas II SD Negeri 35 Pegambiran Semester II tahun ajaran 2010/2011. Ini terbukti pada penelitian pra siklus rata-rata hasil belajar masih 63,33. Mengalami peningktan pada penelitian tindakan siklus II sehingga 59 dapat mencapai nilai diatas kriteria minimum 70 yaitu dengan nilai ratarata 77,08 .

\section{E. Kerangka Pikir}

Penelitian ini bertujuan untuk mengupayakan peningkatan praktek wudhu' dengan menggunakan metode pembiasaan. Kerangka konseptual merupakan kerangka berfikir penulis tentang pelaksanaan penelitian, sehingga memudahkan peneliti dalam melaksanakan penelitian ini.

Adapun kerangka berfikir peneliti, diawali dengan adanya kondisi factual yakni ditemui permasalahan pada siswa kelas II di SD 44 Sungai Lareh, yaitu kurangnya praktek wudhu'. Peneliti berharap, aktivitas siswa dalam belajar PAI meningkat dari sebelumnya. Oleh karena itu peneliti perlu melakukan sesuatu tindakan yang berupa penggunaan metode pembiasaan dalam pembelajaran PAI dengan kemempuan mengajukan ide-ide pokok dan ide-ide penunjang dalam pembelajaran yang berlangsung. Adapun kegunaan metode pembiasaan ini dalam pembelajaran adalah untuk : (1) membantu siswa belajar dalam membiasakan praktek wudhu' (2) menggolongkan informasi yang mendapatkan akses seketika atau daya ingat yang sempurna.

Dalam penelitian ini, penggunaan metode pembiasaan dalam pembelajaran PAI difokuskan untuk meningkatkan dua hal berikut :

1. Peningkatan kemampuan siswa mengidentifikasi ide-ide pokok dalam pembelajaran PAI.

2. Peningkatan kemampuan siswa mengidentifikasi ide-ide penunjang dalam pembelajaran PAI.

Penjelasan diatas dapat disimpulkan dalam bagan sebagai berikut:

Bagan 1.

Kerangka Konseptual

\begin{tabular}{|c|c|c|c|c|c|c|}
\hline Siswa & 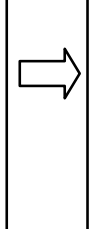 & $\begin{array}{c}\text { Metode } \\
\text { pembiasaan }\end{array}$ & $\Rightarrow$ & $\begin{array}{l}\text { Kemampuan } \\
\text { mengajukan ide-ide } \\
\text { pokok dan ide-ide } \\
\text { penunjang }\end{array}$ & 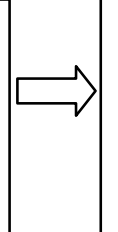 & $\begin{array}{c}\text { Akhirnya: } \\
\text { Aktifitas belajar } \\
\text { meningkat }\end{array}$ \\
\hline
\end{tabular}

\section{F. Hasil Penelitian}

SD Negeri 44 Sungai Lareh merupakan salah satu sekolah dasar negeri yang beralamat di Jl. Pertanian No. 18 Kelurahan Lubuk Minturun Kecamatan Koto Tangah Kota Padang. Sekolah berada di belakang perumahan warga. Sekolah berdiri pada tanah yang luasnya $148 \mathrm{~m} 2$.. berikut ;

Sedangkan data siswa SD Negeri 44 Sungai Lareh dalam tiga tahun terakhir sebagai

\section{Tabel 1.}


Data Siswa SDN 44 Koto Tangah

\begin{tabular}{|c|c|c|c|c|c|}
\hline \multirow{2}{*}{ No } & \multirow{2}{*}{ Kelas } & \multicolumn{3}{|c|}{ Jumlah } & \multirow{2}{*}{ Jumlah } \\
\cline { 3 - 5 } & & $2013 / 2014$ & $2014 / 2015$ & $2015 / 2016$ & \\
\hline 1 & I & 15 & 19 & 15 & 49 \\
\hline 2 & II & 22 & 16 & 19 & 57 \\
\hline 3 & III & 15 & 18 & 18 & 51 \\
\hline 4 & IV & 16 & 14 & 17 & 47 \\
\hline 5 & V & 11 & 11 & 14 & 36 \\
\hline 6 & VI & - & 10 & 10 & 20 \\
\hline \multicolumn{5}{|c}{ Jumlah } \\
\hline
\end{tabular}

Sumber : Data SDN 44 Sungai Lareh Tahun 2016, Wawancara dengan Kepala Sekolah

\section{A. Peningkatan Praktek Berwudhu' melalui Metode Demonstrasi bagi Siswa Kelas II di SDN 44 Koto Tangah Padang}

Penelitian tindakan kelas ini dimulai dengan melakukan observasi awal di SDN 44 Koto Tangah Padang. Sebelum diadakan penelitian, penulis melakukan analisis kebutuhan terlebih dahulu. Dari analisis kebutuhan diperoleh gambaran mengenai situasi dan kondisi belajar tempat penelitian diadakan. Analisis kebutuhan ini dilakukan dengan observasi aktivitas siswa dalam proses pembelajaran. Kegiatan ini bertujuan untuk mengetahui aktivitas siswa dalam pembelajaran, terutama keterampilan dalam melaksanakan wudhu.

Pelaksanaan metode demontrasi dalam pembelajaran wudhu di SDN 44 Koto Tangah dilakukan oleh guru yang mengajar mata pelajaran PAI. Untuk mengetahui secara langsung, sudah tergambar pada hasil observasi penulis pada tanggal 3 Juni 2015 sebagaimana terdapat pada tabel di bawah ini;

Tabel 2.

Peningkatan Praktek Berwudhu' melalui Metode Demonstrasi bagi Siswa Kelas II di SDN 44 Koto Tangah Padang

\begin{tabular}{|l|l|c|c|c|}
\hline \multirow{2}{*}{ No } & \multicolumn{1}{|c|}{ Jenis Kegiatan } & \multicolumn{2}{|c|}{ Realisasi } & \multirow{2}{*}{ Ket } \\
& \multicolumn{1}{|c|}{ Ya } & Tidak & \\
\hline 1 & $\begin{array}{l}\text { Sebelum pembelajaran dimulai, siswa duduk dengan rapi } \\
\text { di bangku masing-masing }\end{array}$ & $\sqrt{ }$ & & \\
\hline 2 & $\begin{array}{l}\text { Siswa memulai pembelajaran dengan membaca do'a yang } \\
\text { dipimpin oleh ketua kelas }\end{array}$ & $\sqrt{ }$ & & \\
\hline 3 & $\begin{array}{l}\text { Siswa mendengarkan apersepsi yang dijelaskan guru yang } \\
\text { berkaitan dengan materi apa yang akan dipelajari }\end{array}$ & $\sqrt{ }$ & & \\
\hline 4 & $\begin{array}{l}\text { Siswa menjawab pertanyaan guru tentang materi } \\
\text { terdahulu }\end{array}$ & $\sqrt{ }$ & & \\
\hline 5 & $\begin{array}{l}\text { Siswa menyiapkan perlengkapan belajar } \\
\text { Sebelum kegiatan inti dimulai, siswa sudah duduk dengan } \\
\text { rapi dan tenang di bangku masing-masing }\end{array}$ & $\sqrt{ }$ & & \\
\hline 7 & $\begin{array}{l}\text { Siswa mendengarkan guru yang menjelaskan materi yang } \\
\text { akan dipelajari }\end{array}$ & $\sqrt{ }$ & & \\
\hline 8 & $\begin{array}{l}\text { Siswa mengajukan pertanyaan tentang materi yang } \\
\text { dijelaskan guru }\end{array}$ & $\sqrt{ }$ & & \\
\hline 9 & Guru mempraktekkan tata cara berwudhu yang benar & $\sqrt{ }$ & \\
\hline
\end{tabular}




\begin{tabular}{|l|l|l|l|l|}
\hline 10 & $\begin{array}{l}\text { Siswa mengikuti dengan benar apa yang dicontohkan oleh } \\
\text { guru }\end{array}$ & $\sqrt{ }$ & \\
\hline 11 & $\begin{array}{l}\text { Siswa mampu mempraktekkan wudhu sendiri dengan } \\
\text { benar }\end{array}$ & $\sqrt{ }$ & \\
\hline
\end{tabular}

Berdasarkan tabel di atas dapat dipahami bahwa guru telah melaksanakan peningkatan praktek berwudhu melalui metode demonstrasi bagi siswa kelas II SDN 44 Koto Tangah Padang. Hal ini tergambar dalam langkah-langkah yang dilaksanakan dibawah ini;

a. Pada sebelum pembelajaran dimulai, siswa sudah duduk dengan rapi di bangku masing-masing dengan tertib. sebelum proses pembelajaran siswa menyiapkan perlengkapan belajar dan para siswa sudah duduk dengan rapi dan tenang di bangku masing-masing.

b. Selanjutnya siswa memulai pembelajaran dengan membaca do'a yang dipimpin oleh ketua kelas dan dibimbing oleh guru bidang studi.

c. Guru memberikan apersepsi terlebih dahulu.

d. Siswa mendengarkan apa yang dijelaskan guru yang berkaitan dengan materi apa yang akan dipelajari

e. Siswa juga mampu menjawab pertanyaan guru tentang materi terdahulu.

Selanjutnya berdasarkan observasi awal penulis, banyak siswa yang belum terampil dan terbiasa dalam melaksanakan wudhu. Adakalanya siswa melaksanakan wudhu tidak berurutan sesuai dengan rukun-rukunnya. Hal ini dikarenakan siswa tidak terbiasa dalam melaksanakan wudhu, baik di sekolah maupun di rumah masing-masing.

Berdasarkan ulasan di atas tentunya harus ada upaya yang signifikan dalam mengantisipasi tidak terampilnya siswa dalam melaksanakan wudhu. Sehingga siswa akan mampu melaksanakan wudhu dengan benar. penulis berupaya melakukan peningkatan aktivitas siswa dengan metode demontrasi. Adapun langkah-langkahnya adalah sebagai berikut;

4. Pra siklus

a. Perencanaan Tindakan.

Kegiatan perencanaan tindakan meliputi hal berikut;

4) Guru menyampaikan kepada siswa bahwa nantinya beberapa pertemuan ke depan untuk materi wudhu akan diadakan penelitian supaya siswa bisa bekerja sama dengan baik. Dalam hal ini peneliti memasuki kelas yang akan diteliti dengan di dampingi gurukelas. Para siswa sangat bersemangat dengan kegiatan yang akan dilakukan.

5) Guru menentukan materi yaitu tentang kemampuan wudhu siswa. Agar kegiatan dapat berjalan sistematis, maka pembelajaran difokuskan pada materi wudhu. Agar seluruh siswa dapat mengikutinya dengan baik dan benar.

6) Guru menyiapkan administrasi pembelajaran pada materi wudhu yaitu membuat RPP. RPP disini disesuaikan dengan metode demontrasi yang akan dilaksanakan.

e. Pelaksanaan Tindakan

Kegiatan pelaksanaan tindakan meliputi hal berikut;

8) Guru membuka pelajaran dengan berdo'a bersama. Ini merupakan kegiatan penting dalam setiap pembelajaran yang akan dilakukan. Agar proses pembelajaran dapat berjalan dengan baik dan para siswa selalu terbiasa agar setiap memulai pembelajaran didahului dengan pembacaan doa.

9) Guru mengabseni siswa. 
10) Guru melakukan apersepsi sebelum memulai pelajaran, yaitu yang berisi pertanyaan-pertanyaan tentang pelajaran yang lalu dan juga berisi motivasi tentang tujuan dan manfaatnya ketika mempelajari materi berwudhu.

11) Guru memulai masuk proses pembelajaran dengan menerangkan dan sunnah wudhu, syarat air yang bisa digunakan berwudhu dan manfaat kita melakukan wudhu.

12) Guru menjelaskan materi wudhu hanya menggunakan metode konvensional saja (ceramah). Dalam hal ini sebenarnya peneliti ingin melihat respon yang dimunculkan oleh siswa terkait penggunaan metode ceramah.

13) Sebelum menutup pembelajaran guru memberi kesempatan kepada siswa untuk bertanya jika ada yang masih belum jelas.

14) Guru menyimpulkan pelajaran. Dalam hal ini guru menyampaikan kesimpulan pelajaran dan siswa menyimak dan memperhatikan apa yang disampaikan oleh guru.

f. Observasi

5) Guru memantau proses pembelajaran. Dalam hal ini dilakukan pemantau dalam proses pembelajaran dan bisa mengetahui secara detail tentang proses pembelajaran.

6) Guru mengamati aktifitas siswa. Dalam hal ini guru bisa mengetahui berbagai hal tentang aktifitas siswa.

7) Guru mengamati keselarasan perencanaan terhadap pelaksanaan.

8) Guru mengadakan evaluasi pembelajaran.

Dalam observasi awal siswa telah nampak bahwa siswa kurang terampil dalam mempraktekkan wudhu. Hal ini tentunya karena kurang terbiasanya siswa dalam melaksanakan wudhu.

g. Refleksi

4) Guru mencatat segala hambatan selama melakukan pembelajaran.

5) Guru menganalisa faktor yang menjadi penghalang terjadinya proses pembelajaran.

6) Guru mencari solusi dari fakto-faktor penghambat untuk dijalankan pada siklus selanjutnya

b. Siklus 1

Kegiatan pada siklus I dilaksanakan pada tanggal 1 Februari 2017 membahas tentang implementasi pembelajaran wudhu. Pada tahap perenanaan siklus I, desain pembelajaran yang disiapkan meliputi Rencana Pelaksanaan Pembelajaran (RPP) dengan menggunakan metode demontrasi dimana pada model pembelajaran kooperatif ini, siswa berperan aktif dalam proses pembelajaran berlangsung, dan guru hanya mengawasi ketika siwa melaksanakan implementasi pembelajaran wudhu. Peneliti menyiapkan lembar penilaian berupa instrumen untuk pre dan post test siklus I, instrumen ini digunakan untuk mengetahui hasil belajar siswa setelah pembelajaran berlangsung.

a. Perencanaan Tindakan

8) Menentukan materi yaitu pada standar kompetensi melaksanakan tata cara wudhu pada kompetensi dasar mempraktekkan wudhu di kelas II tahun ajaran 2013/2014.

9) Menentukan metode pembelajaran yaitu menggunakan alat peraga gambar.

10) Menyiapkan rencana pelaksanaan pembelajaran (RPP) dan peraga yang diperlukan.

11) Mengembangkan skenario pembelajaran, dari rencana pembelajaran hingga saat praktek. 
12) Membuat lembar pantauan siswa tentang pelaksanaan wudhu dirumah.

13) Membentuk kelompok yang heterogen. Peserta didik dibagi menjadi 5 (lima) kelompok dengan setiap kelompoknya beranggotakan 6 orang.

14) Menyiapkan format evaluasi yang berupa lembar penilaian tes praktik

b. Pelaksanaan Tindakan

Siklus pertama dilaksanakan pada tanggal 4 Februari 2017 dan tidanakan yang dilakukan adalah melaksanakan pre test terlebih dahulu. Sebelum penelitian di mulai, terlebih dahulu siwa melaksanakan pre test untuk mengukur tingkat kemampuan siswa terhadap materi yang belum di ajarkan. Selanjutnya guru (peneliti) menjelaskan kepada siswa tentang implementasi pembelajaran wudhu dan memberikan gambaran tentang pelaksanaanya. Kemudian siswa melaksanakan praktek pembelajaran wudhu. Dan pembelajaran berakhir dengan melaksanakan post test yang dilakukan oleh seluruh siswa tentang materi wudhu.

7) Setelah menyiapkan apa yang dibutuhkan dalam pembelajaran, termasuk RPP dan peraga, guru mulai mempelajarinya dengan seksama supaya dalam pelaksanaannya bisa berjalan lancar.

8) Guru melaksanakan pembelajaran tentang wudhu dimulai dengan,apersepsi, dikegiatan ini guru memberi motivasi kepada siswa tentang pentingnya, manfaat dan juga hukuman bagi yang meninggalkannya, supaya siswa mengetahui secara mendasar tentang wudhu. Jadi ketika melaksanakan kewajiban wudhu tidak dianggap sekedar sebagai rutinitas, tetapi mengetahui secara substansi arti wudhu tersebut

9) Kemudian dilanjutkan pada kegiatan ini. Pada kegiatan ini guru memulai pembelajaran dari hal yang paling awal orang belajar wudhu, yaitu mengetahui tentang rukun dan sunnah wudhu, dilanjutkan bacaan-bacaannya. Pada tahap ini guru perlu membahas lebih mendalam lagi, tidak sekedar hafal bacaan- bacaan wudhu,tetapi sekalian mengetahui artinya. Karena pada tataran siswa kelas II usia siswa sudah memasuki usia untuk diperintah melaksanakan ibadah secara mandiri.

10) Setelah dirasa siswadalam bacaan sudah bisa kemudian untuk gerakan wudhunya, guru memperlihatkan gambar-gambar orang ketika berwudhu mulai dari awal dicontohkan secara terpotong-potong pada tiap-tiap bagian gerakan wudhu secara sempurna.

11) Setelah guru memperlihatkan secara keseluruahan dan siswa mengamati.

12) Kemudian guru menghimbau kepada para siswa untuk melaksanakan shalat.

B. Hasil Peningkatan Praktek Bewudhu' melalui Metode Demonstrasi bagi Siswa Kelas II SDN 44 Koto Tangah Padang

Observasi dengan mengamati terjadinya aktifitas belajar siswa, dengan ditandai kefasihan melafadzkan bacaan wudhu, kesempurnaan gerakannya, dilihat dari sikap ketika melakukan wudhu. Untuk lebih lanjut, hasil observasi terlihat pada tabel berikut;

Tabel 2.

Peningkatan Praktek Berwudhu melalui Metode Demontrasi

\begin{tabular}{|c|c|c|c|c|c|}
\hline \multirow[b]{2}{*}{ No } & \multirow[b]{2}{*}{ Jenis Kegiatan } & \multicolumn{3}{|c|}{ Realisasi } & \multirow[b]{2}{*}{ Ket } \\
\hline & & $\begin{array}{l}\text { Tidak } \\
\text { Bisa }\end{array}$ & Bisa & $\begin{array}{l}\text { Sanga } \\
\text { t Bisa }\end{array}$ & \\
\hline 1 & $\begin{array}{l}\text { Siswa melafazkan doa sebelum berwudhu } \\
\text { dengan benar }\end{array}$ & & $\sqrt{ }$ & & \\
\hline 2 & Siswa mencuci telapak tangannya dengan baik & & $\sqrt{ }$ & & \\
\hline
\end{tabular}




\begin{tabular}{|c|l|c|c|c|c|}
\hline & dan benar & & & & \\
\hline 3 & Siswa berkumur-kumur sebelum berwudhu & $\sqrt{ }$ & & & \\
\hline 4 & Siswa mencuci hidunya denga baik dan benar & $\sqrt{ }$ & & & \\
\hline 5 & Siswa mencuci wajahnya dengan benar & & $\sqrt{ }$ & & \\
\hline 6 & $\begin{array}{l}\text { Siswa mencuci kedua tangan sampai siku } \\
\text { dengan teratur }\end{array}$ & $\sqrt{ }$ & & & \\
\hline 7 & Siswa menyampu kepalanya dengan benar & & $\sqrt{ }$ & & \\
\hline 8 & Siswa mencuci kedua telinganya dengan benar & $\sqrt{ }$ & & & \\
\hline 9 & $\begin{array}{l}\text { Siswa mencuci kedua kaki sampai siku dengan } \\
\text { benar }\end{array}$ & $\sqrt{ }$ & & & \\
\hline 10 & $\begin{array}{l}\text { Siswa membaca sesudah berwudhu dengan } \\
\text { benar }\end{array}$ & $\sqrt{ }$ & & & \\
\hline
\end{tabular}

Berdasarkan tabel di atas maka dapat dipahami bahwa siswa belum banyak yang terampil dalam melaksanakan wudhu. Hal ini terlihat sebagai berikut;

i. Dalam melafazkan doa, ada beberapa siswa yang bisa melafazkan tetapi tidak semuanya bacaan doa tersebut betul bacaanya dapat dilihat.

ii. Dalam mencuci telapak tangan banyak siswa melakukannya dengan tergesa-gesa, ingin cepat selesai dan kadangkala sambil bercanda dengan teman-temannya. Hal ini tentu sesuai dengan usia kelas II yang lebih suka bermain-main, terutama dalam proses pembelajaran.

iii. Siswa tidak berkumur-kumur dengan benar. Padahal fungsi berkumur-kumur dalam wudhu sangat tepat dalam membersihkan mulut dari kotoran-kotoran. Dan juga mempunyai makna bahwa mulut harus dibersihkan agar terjauh dari perbuatan dosa dan maksiat. Selanjutnya dalam mencuci hidung umumnya siswa tidak bisa. Hal ini tentunya karena kurang dibiasakannya siswa mencuci hidung dalam kegiatan berwudhu.

iv. Dalam melaksanakan siswa yang belum bisa dan terampil. Namun tidak semuanya wajahnya yang terkena air. Anak-anak ingin cepat selesai dan terkesan ingin bermain-main dengan air wudhu tersebut. Di samping itu juga ada keinginan anak-anak ingin bermain air dengan teman-temannya. Hal ini tentunya akan menimbulkan keributan dalam praktek wudhu tersebut.

v. Dalam mencuci kedua tangan sampai siku siswa tidak melakukannya dengan teratur dan tidak semua tangannya yang dibersihkan.

vi. Dalam mencuci kepalanya ada beberapa orang siswa yang mampu melaksanakannya dengan benar.

vii. Dalam mencuci kedua telinga dan mencuci kedua kaki sampai mata kaki para siswa umumnya tidak bisa melakukan dengan benar. Siswa hanya ingin cepat selesai. Hal ini tentunya perlu pengawasan dan bimbingan dari guru agar siswa dapat memprakktekan wudhu dengan benar.

a. Refleksi

Berdasarkan siklus 1 di atas masih banyak kesalahan-kesalahan siswa dalam mempraktekkan wudhu. Sehingganya perlu upaya perbaikan agar siswa dapat melaksanakan wudhu dengan benar.

2. Siklus 2

Kegiatan pada siklus I dilaksanakan pada tanggal 4 Maret 2017 membahas tentang implementasi pembelajaran wudhu. Pada tahap perenanaan siklus I, desain pembelajaran yang disiapkan meliputi Rencana Pelaksanaan Pembelajaran (RPP) dengan menggunakan metode demontrasi dimana pada model pembelajaran kooperatif ini, siswa berperan aktif dalam proses pembelajaran berlangsung, dan guru 
hanya mengawasi ketika siwa melaksanakan implementasi pembelajaran wudhu. Peneliti menyiapkan lembar penilaian berupa instrumen untuk pre dan post test siklus I, instrumen ini digunakan untuk mengetahui hasil belajar siswa setelah pembelajaran berlangsung.

e. Perencanaan

5) Mengidentifikasi masalah berdasarkan refleksi siklus I dan alternatif pemecahan masalahnya.

6) Guru menampung semua permasalan yang muncul setelah siswa melakukan siklus I.

7) Menyusun Rencana Pelaksanaan Pembelajaran (RPP) pada pokok bahasan yang sama dengan materi yyang berbeda dari siklus I melalui pengelolaan kelas yang lebih efektif.

8) Guru menyiapkan kkembali lembar pengamatan yang meliputi lembar pengamatan aktivitas siswa dalam praktek maupun dalam kegiatan pembelajaran.

f. Pelaksanaan Tindakan

Siklus pertama dilaksanakan pada tanggal 4 Maret 2017 dan tidanakan yang dilakukan adalah melaksanakan pre test terlebih dahulu. Sebelum penelitian di mulai, terlebih dahulu siwa melaksanakan pre test untuk mengukur tingkat kemampuan siswa terhadap materi yang belum di ajarkan. Selanjutnya guru (peneliti) menjelaskan kepada siswa tentang implementasi pembelajaran wudhu dan memberikan gambaran tentang pelaksanaanya. Kemudian siswa melaksanakan praktek pembelajaran wudhu. Dan pembelajaran berakhir dengan melaksanakan post test yang dilakukan oleh seluruh siswa tentang materi wudhu.

Kegiatan yang dilaksanakan tahap ini yaitu Pengembangan rencana tindakan II dengan melaksanakan tindakan upaya lebih meningkatkan semangat belajar peserta didik dalam pembelajaran wudhu menggunakan alat peraga gambar yang telah direncanakan. Secara rinci dapat diuraikan sebagai berikut:

6) Guru melaksanakan langkah-langkah kegiatan yang tercantum dalam RPP mulai dari kegiatan awal pembelajaran. Guru lebih menekankan agar siswa lebih fokus dalam belajar dan semangat supaya hasilnya bisa maksimal.

7) Guru menjelaskan materi yang telah direncanakan pada kegiatan inti dimulai dari yang dirasa kurang dari evaluasi pada siklus I, jadi tidak mengulang dari awal, tinggal mengulang yang kurang-kurang saja.

8) Guru selau memantau pada setiap kelompok untuk ikut aktif dalam proses pembelajaran.

9) Setiap kelompok dibentuk ketua untuk selalu mengawasi kelompoknya dan melaporkan hasil kelompoknya. Dan ketua kelompok dipilih dari siswa yang dilihat sudah bisa.

10) Guru bersama para ketua kelompok membahas hasil para anggotanya dan mencari solusi sulit-kesulitan yang dihadapi para siswa.

C. Hasil Peningkatan Praktek Berwudhu melalui Metode Demonstrasi bagi Siswa Kelas II di SDN 44 Koto Tangah Padang

Guru mencatat semua proses yang terjadi dalam tindakan model pembelajaran, mendiskusikan tantang tindakan II yang telah dilakukan, dan juga kesulitan yang mungkin dihadapi para siswa setelah melakukan siklus II.

Tabel 3.

Hasil Peningkatan Praktek Berwudhu melalui Metode Demonstrasi bagi Siswa Kelas II di SDN 44 Koto Tangah Padang 


\begin{tabular}{|c|l|c|c|c|c|}
\hline \multirow{2}{*}{ No Jenis Kegiatan } & \multicolumn{1}{|c|}{ Realisasi } & \multirow{2}{*}{ Ket } \\
\cline { 4 - 5 } & & $\begin{array}{c}\text { Tidak } \\
\text { Bisa }\end{array}$ & Bisa & $\begin{array}{c}\text { Sangat } \\
\text { Bisa }\end{array}$ & Siswa melafazkan doa sebelum berwudhu dengan \\
benar & & & $\sqrt{ }$ & \\
\hline 2 & $\begin{array}{l}\text { Siswa mencuci telapak tangannya dengan baik dan } \\
\text { benar }\end{array}$ & & & $\sqrt{ }$ & \\
\hline 3 & Siswa berkumur-kumur sebelum berwudhu & & $\sqrt{ }$ & & \\
\hline 4 & Siswa mencuci hidunya denga baik dan benar & & $\sqrt{ }$ & & \\
\hline 5 & Siswa mencuci wajahnya dengan benar & & & $\sqrt{ }$ & \\
\hline 6 & $\begin{array}{l}\text { Siswa mencuci kedua tangan sampai siku dengan } \\
\text { teratur }\end{array}$ & & $\sqrt{ }$ & & \\
\hline 7 & Siswa menyampu kepalanya dengan benar & & & $\sqrt{ }$ & \\
\hline 8 & Siswa mencuci kedua telinganya dengan benar & & $\sqrt{ }$ & & \\
\hline 9 & Siswa mencuci kedua kaki sampai siku dengan benar & & $\sqrt{ }$ & & \\
\hline 10 & Siswa membaca sesudah berwudhu dengan benar & & & $\sqrt{ }$ & \\
\hline
\end{tabular}

Berdasarkan tabel di atas maka dapat dipahami bahwa siswa terampil dalam melaksanakan wudhu. Hal ini terlihat ;

1. Dalam melafazkan doa, ada beberapa siswa yang bisa melafazkan semuanya bacaan doa tersebut betul bacaanya. Hal ini tentunya perlu demontrasi lebih lanjut bagi guru agar kualita wudhu siswa dapat meningkat di masa yang akan datang.

2. Dalam mencuci telapak tangan tidak ada lagi siswa melakukannya dengan tergesagesa, ingin cepat selesai dan kadangkala sambil bercanda dengan teman-temannya. Hal ini karena usaha yang sungguh-sungguh yang dilakukan oleh guru dalam praktek wudhu tersebut.

3. Melaksanakan siswa berkumur-kumur dengan benar. Padahal fungsi berkumur-kumur dalam wudhu sangat tepat dalam membersihkan mulut dari kotoran-kotoran. Dan juga mempunyai makna bahwa mulut harus dibersihkan agar terjauh dari perbuatan dosa dan maksiat. Selanjutnya dalam mencuci hidung umumnya siswa suda bisa dan benar dalam pelaksanaannya. Hal ini tentunya karena dibiasakannya siswa mencuci hidung dalam kegiatan berwudhu.

4. Dalam hal rukun wudhu banyak siswa yang bisa dan terampil dan sudah semuanya wajahnya yang terkena air. Anak-anak ingin cepat selesai dan terkesan ingin bermainmain dengan air wudhu tersebut. Di samping itu juga ada keinginan anak-anak ingin bermain air dengan teman-temannya. Hal ini tentunya akan menimbulkan keributan dalam praktek wudhu tersebut.

5. Dalam mencuci kedua tangan sampai siku siswa melakukannya dengan teratur dan semua tangannya yang dibersihkan.

6. Dalam menyapu sebagian kepalanya ada beberapa orang siswa yang mampu melaksanakannya dengan benar.

7. Dalam mencuci kedua telinga dan mencuci kedua kaki sampai mata kaki para siswa umumnya bisa dilakukan dengan benar. Hal ini tentunya perlu pengawasan dan bimbingan dari guru agar siswa dapat memprakktekan wudhu dengan benar. 
Berdasarkan hasil siklus 2 di atas maka dapat dipahami bahwa apabila pembelajaran wudhu dilakukan dengan metode Demontrasi maka akan menghasilkan siswa yang terampil dalam melaksanakan wudhu.

\section{Pembahasan}

1. Peningkatan praktek berwudhu melalui metode Demontrasi di kelas II SDN 44 Sungai Lareh Kecamatan Koto Tangah Kota Padang.

Dalam hal peningkatan praktek wudhu dengan menggunakan metode demontrasi telah terbukti pada siklus I dan II. Metode demontrasi merupakan metode yang paling tepat untuk membiasakan peserta didik untuk melaksanakan wudhu. Sehingganya dalam pelaksanaan wudhu ketika akan melaksanakan shalat, para siswa telah terampil. Hal ini tentunya akan mempunyai dampak yang besar. Apabila di kelas II saja anak-anak sudah mampu mempratekkan wudhu dengan baik dan benar, maka tentunya akan berpengaruh dalam usia-usia mereka selanjutnya. Anak-anak akan menjadi generasi yang sangat terbiasa dalam melaksanakan wudhu ketika mau shalat.

Wudhu merupakan ibadah yang sangat penting sebelum melaksanakan shalat. Para orangtua harus mempunyai target agar anak-anaknya harus terampil melaksanakan wudhu. Sedangkan bagi guru merupakan tugas yang sangat penting dalam menghasilkan siswa-siswa yang sangat penting melaksanakan wudhu.

Wudhu merupakan ibadah yang menjadi syarat sah atau tidaknya ibadah shalat seseorang. Dengan demikian wudhu menjadi penentu dalam hal ibadah umat Islam. Oleh karena itu, wudhu harus dilakukan sesuai dengan rukun dan syarat secara baik dan benar, tanpa adanya kesalahan-kesalahan.

2. Hasil siswa terhadap peningkatan praktek berwudhu melalui Metode Demontrasi di kelas II SDN 44 Sungai Lareh Kecamatan Koto Tangah Kota Padang.

Respon siswa dalam proses pembelajaran merupakan sesuatu yang sangat penting. Pembelajaran yang menarik akan meningkatkan respon siswa. Respon merupakan salah satu indikator bahwa pembelajaran menarik bagi siswa dan guru terampil dalam mengelola proses pembelajaran.

Respon siswa dalam proses pembelajaran praktek berwudhu dengan metode demontrasi di Kelas II SDN 44 Sungai Lareh Kecamatan Koto Tangah Padang sangat tinggi. Hal dikarenakan usia anak kelas II SD lebih suka belajar sambil bermain. Dengan demikian, guru harus mampu dan terampil dalam memilih metode pembelajaran yang disesuaikan dengan materi. Di samping itu, juga harus memperhatikan faktor anak dalam menerima pembelajaran.

Materi yang sangat penting bagi siswa akan menjadi sesuatu yang tidak berguna dan bermakna bagi mereka, kalau tidak menggunakan metode yang tepat. Selanjutnya materi yang biasa-biasa saja apabila digunakan dengan metode yang tepat, maka respon siswa akan meningkat dalam proses pembelajaran.

Penggunaan metode demontrasi dalam pembelajaran wudhu sangat tepat, karena bisa meningkatkan respon siswa dan meningkatkan motivasi belajar. Dan tentunya akan meningkatkan kemampuan dan hasil belajar siswa.

3. Faktor pendukung dan faktor penghambat dalam peningkatan praktek berwudhu melalui metode demontrasi bagi siswa kelas II di SDN 44 Sungai Lareh Kecamatan Koto Tangah Padang.

Faktor pendukung dalam penggunaan metode Demontrasi dalam peningkatan praktek berwudhu bagi siswa kelas II SDN 44 Koto Tangah yaitu;

1. Dapat menghemat waktu dan tenaga dengan baik

2. Demontrasi tidak hanya berkaitan dengan aspek lahiriah saja tetapi juga berhubungan dengan aspek batiniah. 
3. Demontrasi dalam sejarah tercatat sebagai metode yang paling berhasil dalam pembentukan kepribadian anak.

Adapun faktor penghambat pada pada metode demontrasi antara lain sebagai berikut:

a. Dalam penggunaan metode demontrasi dalam pengingkatan praktek berwudhu siswa banyak merasa bosan..

b. Bila suatu kebiasaan penggunaan metode Demontrasi sudah tertanam pada diri siswa, sulit untuk dihilangkan.

c. Semua siwa Anak belum dapat mengidentifikasi antara yang benar dan salah.

d. Waktu yang disediakan dalam mata pelajaran PAI kurang memadai.

e. Sarana yang disediakan kurang memadai.

4. Upaya Guru dalam Mengatasi Faktor Penghambat dalam peningkatan prakek berwudhu dengan penggunaan Metode Demonstrasi bagi siswa kelas II di SDN 44 Sungai Lareh Kecamatan Koto Tangah Padang

Penggunaan metode dalam sebuah pembelajaran tentu saja akan dihadapkan kepada faktor pendukung atau penghambat. Faktor pendukung akan menjadi nilai positif dalam kelancaran proses pembelajaran. Sedangkan faktor penghambat yang akan menjadi pengganggu tercapai atau tidaknya tujuan pembelajaran.

Adapun upaya guru mengatasi faktor penghambat peningkatan praktek berwudhu dengan menggunakan metode Demontrasi di Kelas II SDN 44 Koto Tangah adalah sebagia berikut;

a. Guru memperlihatkan gabat pelaksanaan berwudhu. Hal ini tentunya sangat tepat dalam duniaa anak-anak. Sehingga proses pembelajaran akan berlangsung menyenangkan.

b. Guru menyuruh siswa mempraktekkan berwudhu dengan benar dan sempurna.

\section{E. Simpulan dan Saran}

1. Kesimpuan

a. Peningkatan praktek berwudhu melalui metode Demontrasi di kelas II SDN 44 Sungai Lareh Kecamatan Koto Tangah Padang telah terbukti pada siklus I dan II. Metode demontrasi merupakan metode yang paling tepat untuk membiasakan peserta didik untuk melaksanakan wudhu. Sehingganya dalam pelaksanaan wudhu ketika akan melaksanakan shalat, para siswa telah terampil. Hal ini tentunya akan mempunyai dampak yang besar. Apabila di kelas II saja anak-anak sudah mampu mempratekkan wudhu dengan baik dan benar, maka tentunya akan berpengaruh dalam usia-usia mereka selanjutnya. Anak-anak akan menjadi generasi yang sangat terbiasa dalam melaksanakan wudhu ketika mau shalat.

b. Respon siswa terhadap peningkatan praktek berwudhu melalui Metode Demontrasi di kelas II SDN 44 Sungai Lareh Kecamatan Koto Tangah Padang sangat tinggi. Hal dikarenakan usia anak kelas II SD lebih suka belajar sambil bermain. Dengan demikian, guru harus mampu dan terampil dalam memilih metode pembelajaran yang disesuaikan dengan materi. Di samping itu, juga harus memperhatikan faktor anak dalam menerima pembelajaran.

c. Faktor pendukung dan faktor penghambat dalam peningkatan praktekk wudhu melalui metode Demontrasi bagi siswa kelas II di SDN 44 Sungai Lareh Kecamatan Koto Tangah Kota Padang. Adapaun faktor pendung adalah Dapat menghemat waktu dan tenaga dengan baik, Demontrasi tidak hanya berkaitan dengan aspek lahiriah saja tetapi juga berhubungan dengan aspek batiniah, Demontrasi dalam sejarah tercatat sebagai metode yang paling berhasil dalam pembentukan kepribadian anak. Adapun kekurangan pada metode demontrasi antara lain sebagai berikut: Untuk awal-awal demontrasi anak akan merasa bosan 
melakukannya. Bila suatu kebiasaan sudah tertanam pada diri anak, sulit untuk dihilangkan. Anak belum dapat mengidentifikasi antara yang benar dan salah. Membutuhkan guru yang dapat dijadikan teladan dan mempunyai kepribadian yang baik di mata anak. Membutuhkan waktu bertahap untuk dapat menanamkan suatu kebiasaan pada anak.

d. Upaya yang dilakukan guru dalam mengayatasi faktor penghambat peningkatan praktek wudhu dengna menggunakan metode Demontrasi bagi siswa Kelas II SDN 44 adalah Guru memperlihatkan gabat pelaksanaan berwudhu. Hal ini tentunya sangat tepat dalam duniaa anak-anak. Sehingga proses pembelajaran akan berlangsung menyenangkan dan Guru menyuruh siswa mempraktekkan

\section{Saran} berwudhu dengan benar dan sempurna.

Berdasarkan hasil penelitian ini, penulis memberikan beberapa saran, yaitu;

a. Kepada para guru agar selau melakukan inovasi dalam proses pembelajaran, agar peserta didik selalu bersemangat mengikuti proses pembelajaran, sehingga tujuan pembelajaran yang sudah ditetapkan dapat tercapai dengan baik.

b. Kepada para siswa agar selalu bersemangat mengikuti proses pembelajaran agar berhasil pada masa depan.

c. Kepada Kepala Sekolah agar selalu mengelola proses pembelajaran di satuan pendidikan yang berupaya meningkatkan minat dan motivasi anak, sehingga anakanak tidak bosan dalam mengikuti proses pembelajaran.

d. Kepada Pemerintah tentunya harus meningkatkan perhatian kepada bidang pendidikan, termasuk dalam pengembangan kemampuan guru dalam mengelola proses pembelajaran. Di samping itu, juga perlu adanya pembinaan yang konitiniu agar kemampuan guru selalu dapat ditingkatkan.

\section{Daftar Pustaka}

Abdul Hafidz Suwaid, Muhammad Nur, Mendidik Anak Bersama Nabi, terj. Salafuddin

Abidin Jamaris, Zainal, Pelajaran Bahasa al-Qur'an, (Medan : DDI, 2000)

Adnan Amai, Taufik, Rekonstruksi Sejarah Al Qur'an, (Jakarta : Pustaka Alfabet, 2005)

Agama RI, Departemen, Al Qur'an dan Terjemahnya, (Bandung, Penerbit Diponegoro, 2006)

, Undang-Undang Dasar dan Peraturan Pemerintah RI Tentang Pendidikan, (Jakarta: Direktorat Jenderal Pendidikan Islam, 2006)

Al-Hafidz, Abdul Aziz bin Abdur-Rauuf, Mu'jam Ilmu Al-Lughah An-Nadhary, (Libanon: Maktabah Libnaan, 1982)

Al-Qardhawi, Yusuf, Berinteraksi Dengan Al-Qur'an ( Jakarta : Gema Insani, 1999)

Arifin, H.M, Ilmu Pendidikan Islam Tinjauan Teoritis \& Praktis Berdasarkan Pendekatan Terdisipliner.( Jakarta: Bumi Aksara. 2003)

Arikunto, Suharsimi, Prosedur Penelitian : Suatu Pendekatan Praktek, (Jakarta : Rineka Cipta, 1996)

Enkoswara, Dasar-dasar Metodologi Pengajaran, ( Jakarta : Bina Aksara, 1984) 
http://kbbi.web.id/

Jamal, Syafrudin, Dasar-dasar Metode Penelitian, (Jakarta : The Minangkabau Foundation, 2000)

Maimudin, Yusmanini dkk., Metode Diskusi, ( Jakarta : Depdikbud, 1980)

Muhaimin, Arah Baru Pengembangan Pendidikan Islam: Pemberdayaan, Pengembangan Kurikulum, Hingga Redevisi Islamisasi Pengetahuan (Bandung: Nuansa, 2003)

Munawwir, Ahmad Warson, Kamus Al-Munawwir Arab-Indonesia Terlengkap, (KrapyakYogyakarta: Unit Pengadaan Buku-Buku Ilmiah Ponpes Al-Munawwir, 1991)

Munir, Amin, Samsul, Menyiapkan Masa Depan Anak Secara Islami, (Jakarta : Azmah, 2007), Cet-1

Narbuko dan Abu Ahmadi, Chalid, Metode Penelitian, (Jakarta : Bumi Aksara, 2002)

Nasution, S., Sosiologi Pendidikan, (Jakarta : Bumi Aksara, 1999)

Nawawi, Imam, Adab Mengajarkan Al-Qur'an (Jakarta : Hikmah, 2001)

Prawiradilaga, Dewi Salma, Prinsip Desain Pembelajaran, (Jakarta : Kencana Prenada Media Group, 2008)

Ramayulis, Ilmu Pendidikan Islam, (Jakarta : Kalam Mulia, 2004)

-------------, Ilmu Pendidikan Islam, (Jakarta : Kalam Mulia, 2008)

Sutiah, Buku Ajar Teori Belajar Dan Pembelajaran. (Malang : Universitas Negeri Malang, 2003)

Syarifuddin, Ahmad, Mendidik Anak Membaca, Menulis dan Mencintai Al-Qur'an, (Jakarta: Gema Insani Press, 2004)

Syukri, M., Metodologi Membaca dan Menghafal Al-Qur'an, (Medan : DDI, 2001)

Syuryabrata, Sumardi, Metode Penelitian, (Jakarta : Rajawali, 1991)

Taufiqurrahman, Metode Jibril, ( Malang: Ikatan Alumni PIQ, 2005)

Yusuf, Tayar, Metode Pengajaran al-Qur'an dan Bahasa Arab, (Jakarta : Rajawali Press, 1997)

Zayadi \& Abdul Majid, Ahmad, Pembelajaran Pendidikan Agama Islam (PAI) Berdasarkan Pendekatan Kontekstual, (Jakarta, PT. RajaGrafindo Persada, 2005) 